\title{
GMR
}

\section{Molecular identification of cetaceans from the West Atlantic using the E3-I5 region of COI}

\author{
L.H.O. Falcão ${ }^{1}$, A.S. Campos ${ }^{2}$, J.E.P. Freitas ${ }^{1}$, M.A.A. Furtado-Neto ${ }^{3}$ and \\ V.V. Faria ${ }^{2}$ \\ ${ }^{1}$ Instituto de Ciências do Mar, LABOMAR, Universidade Federal do Ceará, \\ Fortaleza, CE, Brasil \\ ${ }^{2}$ Departamento de Biologia, Universidade Federal do Ceará, Fortaleza, CE, Brasil \\ ${ }^{3}$ Departamento de Engenharia de Pesca, Universidade Federal do Ceará, \\ Fortaleza, CE, Brasil \\ Corresponding author: L.H.O. Falcão \\ E-mail: luarafalcao@gmail.com \\ Genet. Mol. Res. 16 (2): gmr16029607 \\ Received January 12, 2017 \\ Accepted March 28, 2017 \\ Published April 20, 2017 \\ DOI http://dx.doi.org/10.4238/gmr16029607
}

Copyright $(92017$ The Authors. This is an open-access article distributed under the terms of the Creative Commons Attribution ShareAlike (CC BY-SA) 4.0 License.

\begin{abstract}
Molecular identification is very useful in cases where morphology-based species identification is not possible. Examples for its application in cetaceans include the identification of carcasses of stranded animals in advanced state of decomposition and body parts that are illegally traded. One DNA region that is often used for molecular identification is the Folmer region of the mitochondrial gene cytochrome c oxidase subunit I (COI) (locus 48 to $705 \mathrm{bp}$ ). This locus has been used for the identification of several animal species, including whales and dolphins. The goal of the present study was to evaluate the usefulness of another region of COI, the E3-I5 (locus 685 to locus 1179; $495 \mathrm{bp}$ ) as a marker for identification of cetaceans from northeastern Canada and northeastern Brazil. The identification markers were successfully obtained for seven cetacean species after performing percent identity and Basic Local Alignment Search Tool analyses. The obtained markers are now publicly available and are useful for the identification of the
\end{abstract}

Genetics and Molecular Research 16 (2): gmr16029607 
endangered blue whale (Balaenoptera musculus), common minke whale (B. acutorostrata), vulnerable sperm whale (Physeter macrocephalus), harbor porpoise (Phocoena phocoena), common bottlenose dolphin (Tursiops truncatus), Guiana dolphin (Sotalia guianensis), and melonheaded whale (Peponocephala electra).

Key words: Species identification; Endangered species; Molecular marker; Whale; Dolphin

\section{INTRODUCTION}

Cetaceans comprise at least 92 whale and dolphin species that are globally distributed in marine and riverine environments (Perrin, 2017). Whales and dolphins have been the subject of several studies, including those related to their behavior (Rendell and Whitehead, 2001; Visser et al., 2016), strandings (Meirelles et al., 2009, 2010; Truchon et al., 2013), geographical range (Pompa et al., 2011; Attard et al., 2016; Di Tullio et al., 2016), conservation (Pompa et al., 2011), bycatch (Lewison et al., 2004), and taxonomy (Monteiro-Filho et al., 2002). Cetaceans have also been studied using molecular markers for delimitation of species (Cunha et al., 2005) and population lineages (Torres-Florez et al., 2014), molecular phylogeny (Leduc et al., 1999), and molecular identification through the use of molecular markers (Phipps et al., 1998; Dizon et al., 2000; Sholl et al., 2008; Amon et al., 2013).

Molecular markers are, in some cases, the only way to identify a cetacean species. This is the case, for example, of stranded carcasses, which can be difficult to identify by their morphological characters, depending on how degraded it is. Similarly, they are useful in situations when isolated parts of cetaceans are illegally traded. In all these cases, molecular markers have the potential for aiding the successful identification of species. These markers include, for example, the mitochondrial cytochrome b (Phipps et al., 1998; Dizon et al., 2000; Gravena et al., 2008; Sholl et al., 2008; Tsai et al., 2013; Cypriano-Souza et al., 2016), and the control region [(Dizon et al., 2000; Cypriano-Souza et al., 2016); however, see Dizon et al. (2000) for failure in identifying the species of Stenella, Tursiops, and Delphinus complex using the control region].

Currently, the approach that is mostly used for molecular identification of animals is DNA barcoding. This method uses DNA sequences from the initial portion (the Folmer region; locus 48 to 705 ) of the cytochrome oxidase c subunit I (COI) gene for species identification (Hebert et al., 2003). This method can be accessed through BOLD-Barcode of Life Data Systems (http://www.boldsystems.org/) - an online database that hosts COI sequences with certified species identification (Kochzius, 2009).

Despite the vast application of the DNA Barcode method for animal identification, focused on the Folmer region, this method is not universally efficient for cetaceans. This method has been efficient for identification of several cetacean species (Tsai et al., 2013; Chang et al., 2014; Cypriano-Souza et al., 2016). However, there have been cases in which the Folmer region was not useful for differentiating Delphinus delphis, D. capensis, Stenella coeruleoalba, S. frontalis, and Tursiops truncatus, all of which are species in the family Delphinidae, more specifically in the subfamily Delphininae (Amaral et al., 2007; Viricel and Rosel, 2012; Alfonsi et al., 2013). Therefore, researchers frequently use more than one gene region for species identification (Amaral et al., 2007; Viricel and Rosel, 2012; Alfonsi et al., 2013; Cypriano-Souza et al., 2016).

Genetics and Molecular Research 16 (2): gmr16029607 
Given the fact that, eventually, it is necessary to use other molecular markers in addition to the Folmer region for cetacean identification, a continuous search for markers from different gene regions and species is warranted. It is in this context that we, herewith, provide markers of another region of COI for identification of seven cetacean species potentially involved in strandings and/or in the trade of isolated parts in the West Atlantic waters.

\section{MATERIAL AND METHODS}

\section{Geographical location, species, and gene region}

Partial COI sequences (495 bp) from the E3-I5 region (locus 685 to 1179) were obtained for seven cetacean species (Figure 1). The specimens were sampled between 1986 and 1996 along the coasts of Newfoundland (northeastern Canada) and Ceará State (northeastern Brazil) (Figure 2). The Canadian samples were collected from animals that were stranded on the beaches at Newfoundland coast and stored in the freezers of the Whale Research Group (WRG) at the Memorial University of Newfoundland (MUN) in St. John's. The Brazilian samples were also collected from animals stranded on beaches from Ceará State. They were stored in freezers of the Grupo de Estudo de Cetáceos do Ceará-GECC, at the Instituto de Ciências do Mar - LABOMAR from Universidade Federal do Ceará, in Fortaleza.

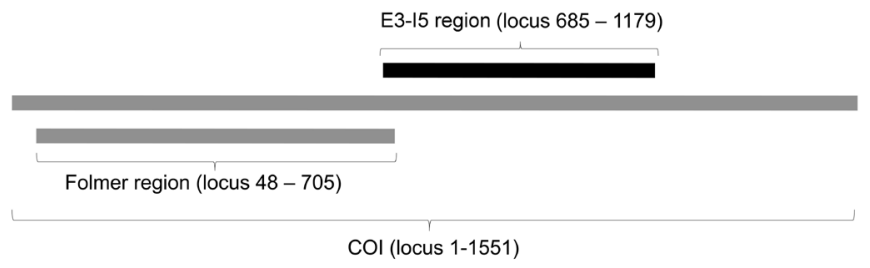

Figure 1. E3-I5 region of the mitochondrial cytochrome oxidase c subunit I (COI) gene used as a molecular marker for identification of cetacean species potentially involved in strandings and/or in the trade of isolated parts in the West Atlantic waters (black bar, with identification of the loci). This region is in contrast to the full COI (larger grey bar) and to the Folmer region, traditionally used in DNA barcoding studies (smaller grey bar). See Lunt et al. (1996) for more details of the E3-I5 region.

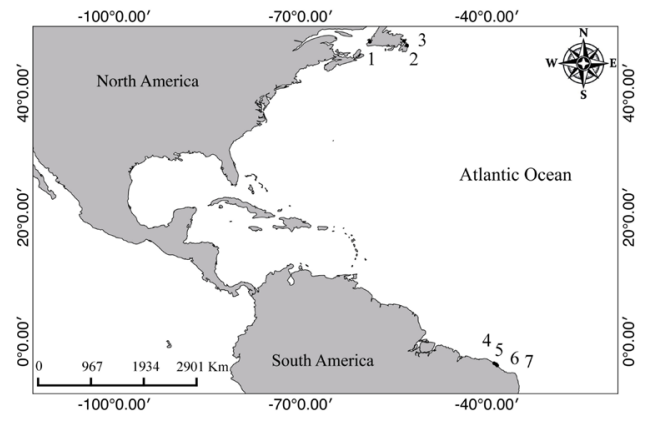

Figure 2. Map showing the six localities (black dots) from where the seven cetacean species (numbers 1 to 7 ) were sampled. Three species sampled from Newfoundland, Canada were: 1) Balaenoptera musculus, St. George's Bay; 2) $B$. acutorostrata, Portugal Cove-St. Philip's; and 3) Phocoena phocoena, Trinity Bay. The remaining four species sampled along the coast of Ceará State, northeastern Brazil were: 4) Physeter macrocephalus, Aquiraz; 5) Peponocephala electra, São Gonçalo do Amarante; 6) Sotalia guianensis, Fortaleza; and 7) Tursiops truncatus, Fortaleza. 


\section{Laboratory procedures}

The DNA was extracted with chloroform:isoamyl alcohol (24:1), precipitated with isopropanol, washed with $75 \%$ ethanol, and resuspended in $50 \mu \mathrm{L}$ distilled water. The polymerase chain reaction (PCR) was used to amplify 495 base pairs (bp) of the mitochondrial DNA cytochrome oxidase subunit I (COI) using the following primers (Integrated DNA Technologies, Inc): COIf-L 5'-CCTGCAGGAGGAGGAGAYCC-3' and COIe-H 5'-CCAGAGATTAGAGGGAATCAGTG-3' (Kessing et al., 1989). The amplification reaction was performed in $100 \mu \mathrm{L}$ solution containing $1.96 \mathrm{mM} \mathrm{MgCl}_{2}, 67 \mathrm{mM}$ Tris- $\mathrm{HCl}, \mathrm{pH} 9.0$, $9.94 \mathrm{mM} \beta$-mercaptoethanol, $0.2 \mathrm{mM}$ each dNTP, $2 \mu \mathrm{L}$ isolated DNA, $0.4 \mu \mathrm{L}$ each primer, 1-3 U AmpliTaq ${ }^{\mathrm{TM}}$ DNA Polymerase (Perkin-Elmer Cetus, Mississauga, ON, Canada). The amplification conditions were as follows: $5 \mathrm{~min}$ at $95^{\circ} \mathrm{C}, 35$ cycles of $1 \mathrm{~min}$ at $93^{\circ} \mathrm{C}, 1 \mathrm{~min}$ at $40^{\circ} \mathrm{C}$, and $30 \mathrm{~s}$ at $55^{\circ} \mathrm{C}$, and $2 \mathrm{~min}$ at $72^{\circ} \mathrm{C}$, and a final extension for $10 \mathrm{~min}$ at $72^{\circ} \mathrm{C}$. The electrophoresis of the $5 \mu \mathrm{L}$ PCR product mixed with $1 \mu \mathrm{L}$ dye was performed on $2 \%$ agarose gel in $1 \mathrm{M}$ TBE buffer. The purification of PCR products was performed using Wizard ${ }^{\mathrm{TM}}$ Magic PCR Preps DNA Purification System (Promega Corp., Madison, WI, USA), following the manufacturer instructions. The forward and reverse strands were sequenced on an Automated DNA Sequencer ABI373A (Applied Biosystems, Inc., Foster City, CA, USA).

\section{Molecular identification: BLAST}

The sequences were checked for their potential as markers for species identification. Each sequence was analyzed using Basic Local Alignment Search Tool (BLAST) (Altschul et al., 1990) available on the website of the National Center for Biotechnology Information - NCBI (https://blast.ncbi.nlm.nih.gov/Blast.cgi). More specifically, the sequences were assessed using BLASTn analysis and Megablast. BLASTn is most appropriate for short input queries, for the identification of short matches, and for cross-species search, whereas Megablast is most appropriate for sequence identification and intra-species comparison (NCBI, 2016). Both analyses were performed using the default parameters and gave the same results. Only the matches with E-value of 0.0 were considered, because they imply an almost zero probability of the alignment occurring by chance. This procedure worked as expected for six out of the seven E3-I5 COI sequences obtained; the $S$. guianensis sequence did not produce any BLASTn or Megablast output. This led us to perform an alternative crosscheck of the obtained S. guianensis DNA sequence as detailed below.

\section{Preparation for percent identity analysis: Checking the identity of Sotalia guianensis complete mitochondrial sequences available in GenBank}

The BLASTn and Megablast trials did not produce any output for $S$. guianensis because of the absence of homologous sequences for this species/genus available for BLAST analysis in GenBank. This was unexpected because GenBank does have a total of six complete mitochondrial genome sequences of $S$. guianensis (GenBank accession Nos. JF681039 and KM893424) and its congener S. fluviatilis (GenBank accession Nos. JF681040, KM893423, KM893421, and KM893422). The reason for this unavailability of Sotalia sequences for BLAST analysis is that these sequences are currently designated as 'unverified' in GenBank.

To help confirm the identity of the 'unverified' complete mitochondrial genome sequences

Genetics and Molecular Research 16 (2): gmr16029607 
of $S$. guianensis and S. fluviatilis, we performed a phylogenetic analysis using the mitochondrial cytochrome $b$ gene, which is also available in GenBank. The idea behind this procedure was that if the identity of each 'unverified' mitochondrial genome sequences was confirmed, we would have a species-certified COI gene region available for comparison. This would then permit us to test whether the E3-I5 COI sequence used in the present study could correctly assign the species. For instance, having a certified $S$. guianensis COI sequence, a percent identity analysis could serve as an immediate alternative to the unavailable BLAST analysis.

The aforementioned phylogenetic analysis based on cyt $b$ was then performed as follows. First, we built a 365-bp dataset including the six 'unverified' complete mitochondrial sequences and all the other sequences available in GenBank for S. guianensis and S. fluviatilis. These included $S$. guianensis DQ086827 and S. fluviatilis DQ086828 sequences (i.e., the ones included in the analysis that revealed that the marine and riverine ecotypes of Sotalia are different species; Cunha et al., 2005). Our analysis also included one sequence from the northeastern coast of Brazil (S. guianensis, GenBank accession No. KJ879244) and another from the Amazon ( $S$. fluviatilis, GenBank accession No. KJ879249) (Falcão et al., 2014). Finally, the sequences of $T$. truncatus and Steno bredanensis were included as outgroups for the analysis.

The cyt $b$ sequences were aligned in Geneious 7.1.5 using MAFFT v7 (Katoh et al., 2002). The crosschecking revealed that four of the six 'unverified' sequences (GenBank accession Nos. KM893424, KM893423, KM893421, and KM893422) had unexpected stop codons along the sequence. These were excluded from the alignment. The two remaining 'unverified' sequences were S. guianensis JF681039 and S. fluviatilis JF681040.

After finalizing the alignment, we selected the most appropriated model of evolution using jModelTest 2 (Guindon and Gascuel, 2003; Darriba et al., 2012), following a Bayesian selection criteria. The analysis suggested Hasegawa-Kishino-Yano (HKY) as the most appropriate model. A Maximum Likelihood (ML) phylogenetic analysis was then performed on PhyML (Guindon and Gascuel, 2003), which is also implemented in Geneious. Finally, the identity of each of the two 'unverified' sequences, S. guianensis JF681039 and S. fluviatilis JF681040, was confirmed (Figure 3).

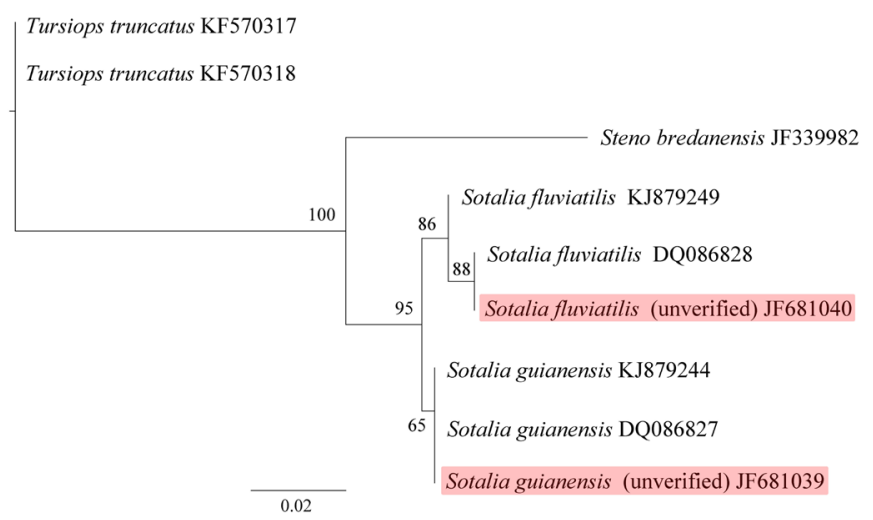

Figure 3. Verification of the identity of GenBank's 'unverified' complete mitochondrial DNA sequences for Sotalia guianensis JF681039 and Sotalia fluviatilis JF681040. The Maximum Likelihood tree based on the partial cytochrome $b$ sequences shows that these 'unverified' sequences have, in fact, correct identities. The respective GenBank accession No. for each sequence is provided. The tree output obtained on Geneious was edited using FigTree (http://tree.bio.ed.ac.uk/software/figtree/).

Genetics and Molecular Research 16 (2): gmr16029607 


\section{Molecular identification: percent identity analysis of COI}

Once the identity of each 'unverified' complete mitochondrial DNA sequence was confirmed by the cyt $b$ analysis, we built a 495 bp COI dataset. This COI dataset included the seven sequences from the E3-I5 region obtained in the present study and nine homologous sequences available in GenBank. The DNA sequences obtained from GenBank were: B. musculus (X72204), B. acutorostrata (GenBank accession No. AP006468), P. macrocephalus (GenBank accession No. KC312603), P. phocoena (GenBank accession No. AJ554063), P. electra (GenBank accession No. JF289176), S. guianensis (GenBank accession No. JF681039), T. truncatus (GenBank accession No. FJ590428), Hippopotamus amphibius (GenBank accession No. AP003425), and S. fluviatilis (GenBank accession No. JF681040). This COI dataset was then submitted to ML analysis. This was done in order to obtain percent identity values, which in turn were crosschecked with the percent identity values obtained after BLAST analyses. The same methodology as described above for the Cyt $b$ ML analysis was followed for this COI ML analysis, except for the model of evolution. The model of evolution adopted for the COI dataset was the HKY $+\mathrm{G}$ $($ gamma $=0.163)$.

\section{RESULTS}

The E3-I5 region of the cytochrome c oxidase subunit I (COI) sequences obtained from all the seven species showed high percent identity with the DNA sequence(s) available in GenBank for their respective species. For the six species that were available for BLAST analysis in GenBank, BLAST and the percent identity (based on maximum likelihood analysis) values varied between 99 and $100 \%$ (Table 1). As for the only species that was unavailable for BLAST, Sotalia guianensis, the percent identity value obtained was $99 \%$ (Table 1) (See Figure 4 for a maximum likelihood tree including all seven studied cetacean species displaying clades of conspecific sequences and showing a match between present study and GenBank sequences).

Table 1. Percent identity values between sequences of the E3-I5 region of the mitochondrial DNA cytochrome oxidase c subunit I (COI) gene obtained in the present study for cetaceans from Canada and Brazil (West Atlantic) and a DNA sequence from its respective congener available in the online database GenBank. BLAST scores for each comparison had E-value $=0$. Percent identity values were obtained after BLAST and Maximum Likelihood (ML) analyses.

\begin{tabular}{|c|c|c|}
\hline Species (GenBank accession No.: present study/GenBank) & Percent identity-BLAST & Percent identity-ML \\
\hline \multicolumn{3}{|l|}{ Balaenopteridae } \\
\hline Balaenoptera musculus KX079489/ X72204.1 & $99 \%$ & $99 \%$ \\
\hline Balaenoptera acutorostrata KX079490/AP006468.1 & $99 \%$ & $99 \%$ \\
\hline \multicolumn{3}{|l|}{ Physeteridae } \\
\hline Physeter microcephalus KX079491/ KC312603 & $100 \%$ & $99 \%$ \\
\hline \multicolumn{3}{|l|}{ Phocoenidae } \\
\hline Phocoena phocoena KX079493/AJ554063.1 & $99 \%$ & $99 \%$ \\
\hline \multicolumn{3}{|l|}{ Delphinidae } \\
\hline Peponocephala electra KX079494/JF289176.1 & $99 \%$ & $99 \%$ \\
\hline Tursiops truncates KX079496/FJ590428.1 & $99 \%$ & $99 \%$ \\
\hline Sotalia guianensis KX079497/JF681039* & $\mathrm{N} / \mathrm{A}$ & $99 \%$ \\
\hline
\end{tabular}

*The JF681039 sequence is not available for BLAST analysis in GenBank due to its status as 'unverified'.

Genetics and Molecular Research 16 (2): gmr16029607 


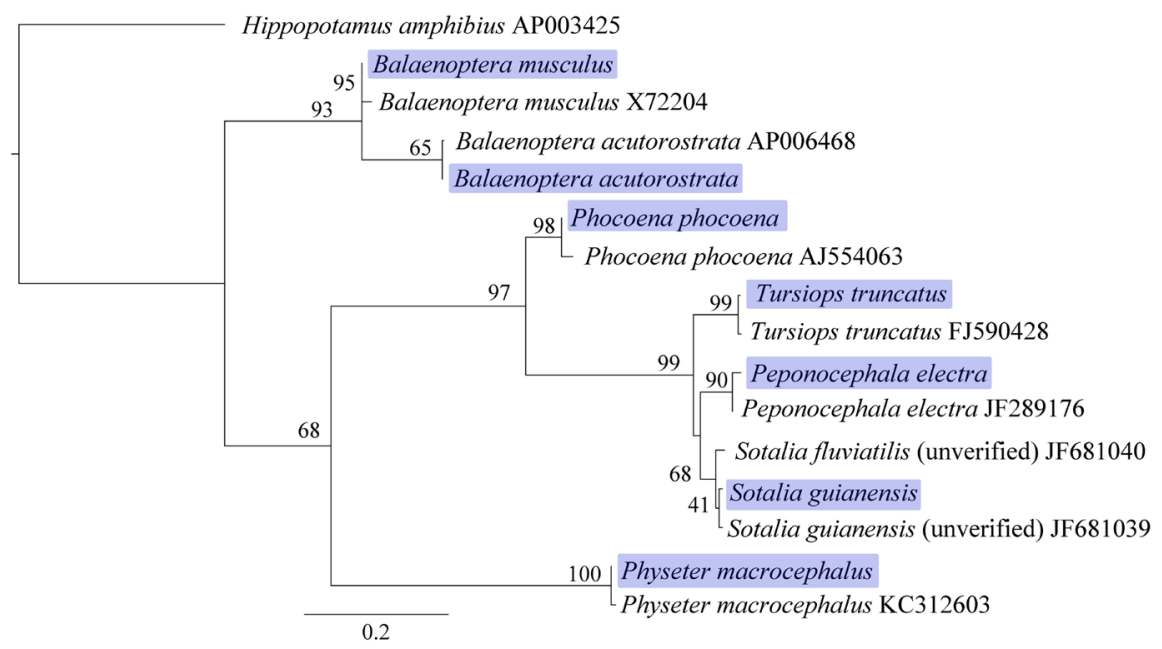

Figure 4. Clades of conspecific sequences for the seven studied cetacean species showing a match between present study (highlighted in purple) and GenBank sequences. Maximum likelihood tree based on an I3-E5 region of the mitochondrial COI gene. The tree output obtained on Geneious was edited using FigTree (http://tree.bio.ed.ac.uk/ software/figtree/).

\section{DISCUSSION}

Here we provide markers that are suitable for molecular identification of seven species of whales and dolphins that occur in West Atlantic waters. The efficiency of this identification was confirmed through the BLAST analysis and the values of percent identity. One of these markers is useful for the identification of the largest animal on Earth (Attard et al., 2016): the blue whale, B. musculus. This species is distributed globally and is considered an endangered species (Reilly et al., 2008).

The markers here proposed are potentially useful in a hot spot of cetacean strandings. This is because the State of Ceará, from where four of our samples were collected, is well known for cetacean strandings. For instance, a carcass of the Omura's whale, B. omurai, stranded in Ceará was recently identified with the aid of molecular tools (Cypriano-Souza et al., 2016). Still, the present study provides the first COI sequence to be available for BLAST analysis in GenBank for the most stranded species along the coast of Ceará, S. guianensis (Meirelles et al., 2010). In addition, at least two other species for which markers were developed in the present study, namely T. truncatus and P. electra, are also know to strand along the coast of Ceará (Meirelles et al., 2009). Also Canada, from where three of our samples were collected, is known for cetacean strandings (Carr et al., 2002).

In addition to carcass identification, the markers generated here are also potentially useful for monitoring the trade of the isolated parts of dolphins and whales. The capture or trade of any dolphin or whale species is illegal in Brazil (Law 7.643, December 1987). However, in spite of this law, dolphins are incidentally captured and used for consumption or as bait in Ceará (Meirelles et al., 2009), Bahia (Barbosa-Filho et al., 2016), and Rio de Janeiro (Di Beneditto et al., 2001). In addition, dolphin genitalia are sold as love charms in Amazonas and Pará (Sholl et al., 2008). 
Due to these illegal uses and trade of dolphin parts, the need for identification of the stranded cetaceans, both in Canada (Truchon et al., 2013) and Brazil (Meirelles et al., 2009, 2010), and the need for conservation of these animals (Pompa et al., 2011), molecular tools for precise species identification of these animals are critical. The present study helps to fill in this immediate demand by providing an additional region of the COI gene - the E3-I5 region (loci 685 to 1179) - as a marker for molecular identification of seven species of whales and dolphins that occur in West Atlantic waters. The empirical evidence of the efficiency of these markers is supported by the congruence among all the analyses performed, which included BLAST and percent identity.

Species in the Delphininae subfamily have been through recent and rapid processes of speciation and potential hybridization (Amaral et al., 2012). Not surprisingly, it is difficult to successfully apply molecular markers for identification of Delphininae, especially between those from the genera Stenella, Tursiops, and Delphinus (Dizon et al., 2000, Amaral et al., 2007; Viricel and Rosel, 2012; Alfonsi et al., 2013). Due to this, the use of multiple mitochondrial regions or the development of new markers for identification of Delphininae species has been proposed (Viricel and Rosel, 2012). The marker here proposed for the common bottlenose dolphin, Tursiops truncatus, may suggest the use of the I3-E5 region of COI in studies targeting multiple DNA regions of Delphininae species. Nevertheless, further sequencing of this region of COI is suggested in order to assess its potential towards molecular identification of closely related species of the genera Stenella, Tursiops, and Delphinus.

\section{Conflicts of interest}

The authors declare no conflict of interest.

\section{ACKNOWLEDGMENTS}

M.A.A. Furtado-Neto is grateful to S.M. Carr for guidance during his doctoral studies at the Memorial University of Newfoundland, which was completed under a fellowship granted by the Canadian International Development Agency-CIDA. The authors are grateful to A.C.O. de Meirelles (Aquasis), R. Maggioni (UFC), and an anonymous reviewer for invaluable suggestions on the manuscript. We are grateful to Aspen Padilla for language review. Fundação Cearense de Apoio ao Desenvolvimento Científico e Tecnológico - FUNCAP provided a Master in Science fellowship to L.H.O. Falcão; Conselho Nacional de Pesquisa e Desenvolvimento Científico-CNPq provided a Scientific Initiation fellowship to A.S. Campos (Programa PIBIC); Coordenação de Aperfeiçoamento de Pessoal de Nível Superior-CAPES provided a postdoctoral fellowship to J.E.P. Freitas (Programa Nacional de Pós-DoutoradoPNPD).

\section{REFERENCES}

Alfonsi E, Méheust E, Fuchs S, Carpentier FG, et al. (2013). The use of DNA barcoding to monitor the marine mammal biodiversity along the French Atlantic coast. ZooKeys 365: 5-24. http://dx.doi.org/10.3897/zookeys.365.5873

Altschul SF, Gish W, Miller W, Myers EW, et al. (1990). Basic local alignment search tool. J. Mol. Biol. 215: 403-410. http://dx.doi.org/10.1016/S0022-2836(05)80360-2

Amaral AR, Jackson JA, Möller LM, Beheregaray LB, et al. (2012). Species tree of a recent radiation: the subfamily Delphininae (Cetacea, Mammalia). Mol. Phylogenet. Evol. 64: 243-253. http://dx.doi.org/10.1016/j.ympev.2012.04.004

Genetics and Molecular Research 16 (2): gmr16029607 
Amaral AR, Sequeira M and Coelho MM (2007). A first approach to the usefulness of cytochrome $c$ oxidase I barcodes in the identification of closely related delphinid cetacean species. Mar. Freshw. Res. 58: 505-510. http://dx.doi. org $/ 10.1071 / \mathrm{MF} 07050$

Amon JD, Glover AG, Wiklund H, Marsh L, et al. (2013). The discovery of a natural whale fall in the Antarctic deep sea. Deep Sea Res. Part II Top. Stud. Oceanogr. 92: 87-96. http://dx.doi.org/10.1016/j.dsr2.2013.01.028

Attard CR, Beheregaray LB and Möller LM (2016). Towards population-level conservation in the critically endangered Antarctic blue whale: the number and distribution of their populations. Sci. Rep. 6: 22291. http://dx.doi.org/10.1038/srep22291

Barbosa-Filho MLV, Costa-Neto EM and Danilewicz D (2016). Dolphin harpooning off the coast of Bahia, Brazil. Mar. Biodivers. Rec. 9: 42. http://dx.doi.org/10.1186/s41200-016-0046-1

Carr SM, Marshall HD, Johnstone KA, Pynn LM, et al. (2002). How to tell a sea monster: molecular discrimination of large marine animals of the North Atlantic. Biol. Bull. 202: 1-5. http://dx.doi.org/10.2307/1543217

Chang CH, Yao CJ, Yu HY, Liao YC, et al. (2014). A molecular forensic method for identifying species composition of processed marine mammal meats. J. Forensic Leg. Med. 23: 65-69. http://dx.doi.org/10.1016/j.jflm.2014.01.012

Cunha HA, da Silva VMF, Lailson-Brito J, Jr., Santos MCO, et al. (2005). Riverine and marine ecotypes of Sotalia dolphins are different species. Mar. Biol. 148: 449-457. http://dx.doi.org/10.1007/s00227-005-0078-2

Cypriano-Souza AL, Meirelles ACO and Carvalho VL (2016). Rare or cryptic? The first report of an Omura's whale (Balaenoptera omurai) in the South Atlantic Ocean. Mar. Mamm. Sci. 33: 80-95. http://dx.doi.org/10.1111/mms.12348

Darriba D, Taboada GL, Doallo R and Posada D (2012). jModelTest 2: more models, new heuristics and parallel computing. Nat. Methods 9: 772. http://dx.doi.org/10.1038/nmeth.2109

Di Beneditto AP, Ramos RMA and Lima NRW (2001). Os golfinhos: origem, classificação, captura acidental, hábito alimentar. Cinco Continentes Editora, Porto Alegre.

Di Tullio JC, Gandra TB, Zerbini AN and Secchi ER (2016). Diversity and distribution patterns of cetaceans in the subtropical southwestern Atlantic outer continental shelf and slope. PLoS One 11: e0155841. http://dx.doi. org/10.1371/journal.pone. 0155841

Dizon A, Baker CS, Cipriano F, Lento G, et al. (2000). Molecular genetic identification of whales, dolphins and porpoises: proceedings of a workshop on the forensic use of molecular techniques to identify wildlife products in the market place. NOAA Technical Memorandum NMFS NOAA-TM-NMFS-SWFSC- 286, 2000. (National Oceanic and Atmospheric Administration: La Jolla, CA.).

Falcão LH, Furtado-Neto MA, Maggioni R and Faria VV (2014). Prospective molecular markers for the identification of illegally traded angelsharks (Squatina) and dolphin (Sotalia guianensis). Genet. Mol. Res. 13: 9710-9717. http:// dx.doi.org/10.4238/2014.November.24.2

Gravena W, Hrbek T, Silva VMF and Farias IP (2008). Amazon River dolphin love fetishes: from folklore to molecular forensics. Mar. Mamm. Sci. 24: 969-978.

Guindon S and Gascuel O (2003). A simple, fast, and accurate algorithm to estimate large phylogenies by maximum likelihood. Syst. Biol. 52: 696-704. http://dx.doi.org/10.1080/10635150390235520

Hebert PDN, Cywinska A, Ball SL and deWaard JR (2003). Biological identifications through DNA barcodes. P. Roy. Soc. B.-. Biol. Sci. 270: 313-321. http://dx.doi.org/10.1098/rspb.2002.2218

Katoh K, Misawa K, Kuma K and Miyata T (2002). MAFFT: a novel method for rapid multiple sequence alignment based on fast Fourier transform. Nucleic Acids Res. 30: 3059-3066. http://dx.doi.org/10.1093/nar/gkf436

Kessing B, Croom AM, McIntosh C, Mcmillan OW, et al. (1989). The simple fool's guide to PCR. University of Hawaii, Honolulu, HI.

Kochzius M (2009). Trends in fishery genetics. In: The Future of Fisheries Science in North America (Beamish RJ and Rothschild BJ, eds.). Fish Fisheries Series 31: 453-493, Springer Netherlands.

Leduc GR, Perrin WF and Dizon AE (1999). Phylogenetic relationships among the delphinid cetaceans based on full cytochrome $b$ sequences. Mar. Mamm. Sci. 15: 619-648. http://dx.doi.org/10.1111/j.1748-7692.1999.tb00833.x

Lewison RL, Crowder LB, Read AJ and Freeman SA (2004). Understanding impacts of fisheries bycatch on marine megafauna. Trends Ecol. Evol. 19: 598-604. http://dx.doi.org/10.1016/j.tree.2004.09.004

Lunt DH, Zhang DX, Szymura JM and Hewitt GM (1996). The insect cytochrome oxidase I gene: evolutionary patterns and conserved primers for phylogenetic studies. Insect Mol. Biol. 5: 153-165. http://dx.doi.org/10.1111/j.1365-2583.1996.tb00049.x

Meirelles ACO, Monteiro-Neto C, Martins AMA, Costa AF, et al. (2009). Cetacean strandings on the coast of Ceará, northeastern Brazil (1992-2005). J. Mar. Biol. Assoc. U. K. 89: 1083-1090. http://dx.doi.org/10.1017/S0025315409002215

Meirelles ACO, Ribeiro AC, Silva CPN and Soares Filho AA (2010). Records of guiana dolphin, Sotalia guianensis, in the state of Ceará, northeastern Brazil. LAJAM 8: 97-102. http://dx.doi.org/10.5597/lajam00157

Monteiro-Filho ELA, Monteiro LR and Reis SF (2002). Skull shape and size divergence in dolphins of the genus Sotalia: A morphometric tridimensional analysis. J. Mammal. 83: 125-134. http://dx.doi.org/10.1644/1545-

Genetics and Molecular Research 16 (2): gmr16029607 
1542(2002)083<0125:SSASDI $>2.0 . \mathrm{CO} ; 2$

NCBI (2016) BLAST homepage \& search pages. NCBI Handout Series. Available at [ftp://ftp.ncbi.nlm.nih.gov/pub/ factsheets/HowTo_BLASTGuide.pdf]. Last updated on March 18, 2016.

Perrin WF (2017). World Cetacea Database. Available at [http://www.marinespecies.org/cetacea]. Accessed August 8, 2016.

Phipps M, Ishihara A, Kanda N and Suzuki H (1998). A preliminary report on DNA sequence analysis of whale meat and whale meat products collected in Japan. TRAFFIC Bull. 17: 91-94.

Pompa S, Ehrlich PR and Ceballos G (2011). Global distribution and conservation of marine mammals. Proc. Natl. Acad. Sci. USA 108: 13600-13605. http://dx.doi.org/10.1073/pnas.1101525108

Reilly SB, Bannister JL, Best PB, Brown M, et al. (2008). Balaenoptera musculus. The IUCN Red List of Threatened Species 2008. e.T2477A9447146. Available at: [http://dx.doi.org/10.2305/IUCN.UK.2008.RLTS.T2477A9447146. en.].

Rendell L and Whitehead H (2001). Culture in whales and dolphins. Behav. Brain Sci. 24: 309-324, discussion 324-382. http://dx.doi.org/10.1017/S0140525X0100396X

Sholl TGC, Nascimento FF, Leoncini O, Bonvicino CR, et al. (2008). Taxonomic identification of dolphin love charms commercialized in the Amazonian region through the analysis of cytochrome b DNA. J. Mar. Biol. Assoc. U. K. 88: 1207-1210. http://dx.doi.org/10.1017/S002531540800043X

Torres-Florez JP, Hucke-Gaete R, LeDuc R, Lang A, et al. (2014). Blue whale population structure along the eastern South Pacific Ocean: evidence of more than one population. Mol. Ecol. 23: 5998-6010. http://dx.doi.org/10.1111/ mec. 12990

Truchon MH, Measures L, L'Hérault V, Brêthes JC, et al. (2013). Marine mammal strandings and environmental changes: a 15-year study in the St. Lawrence ecosystem. PLoS One 8: e59311. http://dx.doi.org/10.1371/journal.pone.0059311

Tsai LC, Lee JC, Shen LL and Hsieh HM (2013). Identification of the seized meats products for suspected Cetacea. Forensic Sci. J. 12: 9-14.

Viricel A and Rosel PE (2012). Evaluating the utility of coxl for cetacean species identification. Mar. Mamm. Sci. 28: 3762. http://dx.doi.org/10.1111/j.1748-7692.2010.00460.x

Visser F, Curé C, Kvadsheim PH, Lam FPA, et al. (2016). Disturbance-specific social responses in long-finned pilot whales, Globicephala melas. Sci. Rep. 6: 28641. http://dx.doi.org/10.1038/srep28641

Genetics and Molecular Research 16 (2): gmr16029607 